\title{
Assessing digital co-creation in urban transformations: Case of Vilnius
}

\author{
Aelita Skaržauskienè [0000-0003-1606-0676], Vilnius Gediminas Technical University, \\ Vilnius, Lithuania. aelita.skarzauskiene@vgtu.lt
}

Monika Mačiulienè [0000-0002-8527-7468], Mykolas Romeris University,

Vilnius, Lithuania. maciuliene@mruni.eu

Laura Gudelytè [0000-0002-5942-9608], Vilnius Gediminas Technical University, Vilnius, Lithuania. laura.gudelyte@vgtu.lt

\begin{abstract}
Public spaces play a vital role in urban democracy since they enable collective usage and reflection. One of the ways to make open public spaces more attractive and inclusive in modern times full of busyness is through the use of innovative digital technologies. Mobile and Internet-based interventions into public spaces deploy a number of strategies - from gathering data through GIS, syntax mapping to using digital tools to collect ideas and opinions of stakeholders. Digitization may often lead to bottom-up initiatives where the citizens and other stakeholders voluntarily employ their talent and resources to enhance the quality of life and solve problems of urbanized societies. This chapter presents methodological Digital Co-Creation Assessment Framework which considers a variety of aspects in the transformation of open spaces to co-creative systems: socio-cultural contexts, multi-stakeholder perspective, diversity in needs, incentives for participation of different groups and cooperation capabilities. The framework provides a useful approach to explore initiatives of digital co-creation as it allows to identify potential areas of improvement and to compare case studies on common indicators. However, definition of complex socio-technical systems, such as digital co-creation, is unavoidably partial, contextspecific and temporary. To test the applicability of the evaluation tool, the authors have chosen to analyse the transformation of Aukštamiestis district in Vilnius from a private space to a public place by conducting a case study analysis. The transformational nature of selected case study allowed to identify the limitations of proposed model and define the areas of improvement for applicability in varied contexts.
\end{abstract}

Keywords - Co-creation, public places, ICT, urban transformations 


\section{INTRODUCTION}

Urban innovation is a rapidly growing priority for countries everywhere with an increasingly urbanized world's population. Open spaces can be a source of social capital due to its' political, social and symbolic role in the society (Varna \& Tiesdell, 20I0). Politically, the public spaces enable plurality and the ability to express the views. The social value occurs because the public spaces enable social interactions between non-homogenous groups of people. Attractive and inclusive public spaces can serve as a balance for negative aspects of urbanized life (Birch, 20I6). Lastly, the public places serve as symbols of the larger collective identity by signalling the cultural norms. Martinus (2014) explores the public opens spaces as platforms for strengthening the social capital networks and supporting social innovation systems. The author suggests that "there is an economic and policy imperative to better understand the design, location and user perception aspects of urban space as determinants of user attraction" (Martinus, 20I4: 44). Finally, Birch (2016: 123) suggests that "how people access, use, and modify public space often provides an environment in which to study community organization". Hence, the institute of public space enabled to analyse contemporary societal shifts amplified by increased mobility and technology use.
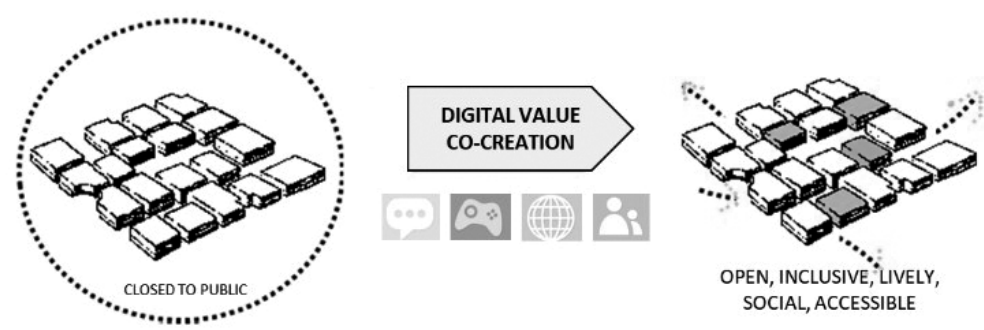

Fig. I: Transforming public spaces through digital co-creation. Source: Authors.

One of the ways to make open public spaces more attractive and inclusive is the use of innovative digital technologies (Fig. I). Mobile and internet-technology based interventions tackling the problem of inclusive public spaces deploy a number of strategies and combine a number of different objectives - from gathering data through GIS, syntax mapping to using digital tools to gather ideas and opinions of stakeholders. Digitization often leads to bottom-up initiatives where the citizens and civic organizations voluntarily lend their talent and resources to help the public entities in solving social problems and enhancing the quality of life. Stewart-Weeks (2010: 83) suggests that "citizens are increasingly willing and able to translate their day-to-day experience into ideas, preferences, and insights that can become powerful resources for innovation". Researchers (Polin et al., 20I7; Shenk et al., 2016) suggest that the inclusion of citizens, especially those who are underrepresented, into urban planning processes is crucial if the cities seek next-generation solutions and more 
connected communities. According to Faga (2006), increased inclusiveness often leads to a stronger sense of ownership in the area.

The co-creative approach is intrinsically user-oriented because it helps the people and organizations to promote their own decisions, develop capacities for open-ended social innovations, rather than invites citizens to participate in existing initiatives (Mačiulienè, 2018). However, the multiple studies on co-creation (Bason, 2015; Bulc, 20I2; Brabham, 2009; Franz, 20I5; Mulder, 20I2), digital tools (Baldersheim \& Kersting, 20I2; Cheliotis, 20I5; Certomà, Dyer, Pocatilu \& Rizzi, 20I7; Poplin, 20I2) and their application in developing public open spaces (POS) as separate subject lack a holistic perspective. In response to the issues discussed herein, following sections demonstrate the relevance of ICT in transforming public spaces by presenting the Digital Co-Creation Assessment Methodology and applying it in studying the transformation of Aukštamiestis in Vilnius City, Lithuania.

\section{DIGITAL CO-CREATION OF PUBLIC SPACES: METHODOLOGICAL ASSESSMENT FRAMEWORK}

The advent of ICT-based engagement tools brings with it both opportunities and challenges. On the one hand, technology has the potential to play a key role in engaging stakeholders and extracting key data. On the other, it may encourage new forms of exclusion - many citizens and potential stakeholders of digital tools have limited or no online access, so the tools may further marginalize those already limited in exerting power. It also continues to focus on segments of society which is already high on privilege scale based on education, tech skills, social class and even race (Rumbul, 2016) thus limiting the expected recreation of civic society. The use of any digital application also involves risks related to information security, privacy, and data protection. Some types of platforms gather personal information of citizens (e.g., location, activities, even political views). If multiple data sets are combined, they might reveal sensitive information. Hence, careful screening and regulations are needed. The use of ICT also has an influence on how we perceive public space. On one hand, the researchers (Castells, 2000) propose that the virtual space might replace physical public spaces since the social interactions mostly occur online. Alternatively, urban planners are opening up the planning processes to involve the citizens in designing public places through direct participation, public meetings, negotiations, and other co-creative measures.

No single factor alone causes the change towards more inclusive and engaging public spaces through digital means. Rather a combination of drivers operates at different levels. Hence, a multi-layered framework is needed to assess co-creative initiatives in public places and detect factors leading to positive urban transformations. For this purpose, a multi-layered evaluation framework - Digital Co-Creation Index - has been designed by C3Places research group. The design of the index adopted a pragmatic mixed research method detailed in this section. The first step 
was to construct a conceptual framework by capturing theoretical influences through analysis of previous research efforts. This exercise provided a structure for framework dimensions. The findings of previous studies such as Collective Intelligence Potential Index (Skaržauskienė et al., 2015), Quality of Experience framework (Möller \& Raake, 20I4), Social Networking Adoption Model (Griggs \& Wild, 20I3) and Dimensions of Space framework (Project for Public Spaces, 2009) were incorporated into further works. Refer to Mačiulienè, Skaržauskienė \& Botteldooren (2018) for an in-depth review of relevant literature.

The theoretical frameworks provide an interpretative approach to the social reality and empirical investigations are needed to test their consistency with the reality (Jabareen, 2009). Based on the literature review, we hypothesize that a set of dimensions are influencing the digital co-creation outcomes. However, there may be different configurations and additional preconditions. So, the second step of the process was the expert interviews. The in-depth knowledge provided by the experts on the key evaluation points is particularly suited for broadening the theoretical framework. Nine purposively sampled semi-structured face-to-face expert interviews were conducted to check and improve the theoretical model. The final step towards the completion of the methodological framework was the preparation of assessment methodology - design of updated framework (See Fig. 2), selection of evaluation criteria and proposal of assessment guidelines. The qualitative data collected during the interviews were analysed in the context of respondents' ideas, arguments and opinions in order to deepen the researchers' understanding of the analysed issues. The findings allowed us to explain the processes of digital co-creation in specific context i.e. design and improvement of public spaces.

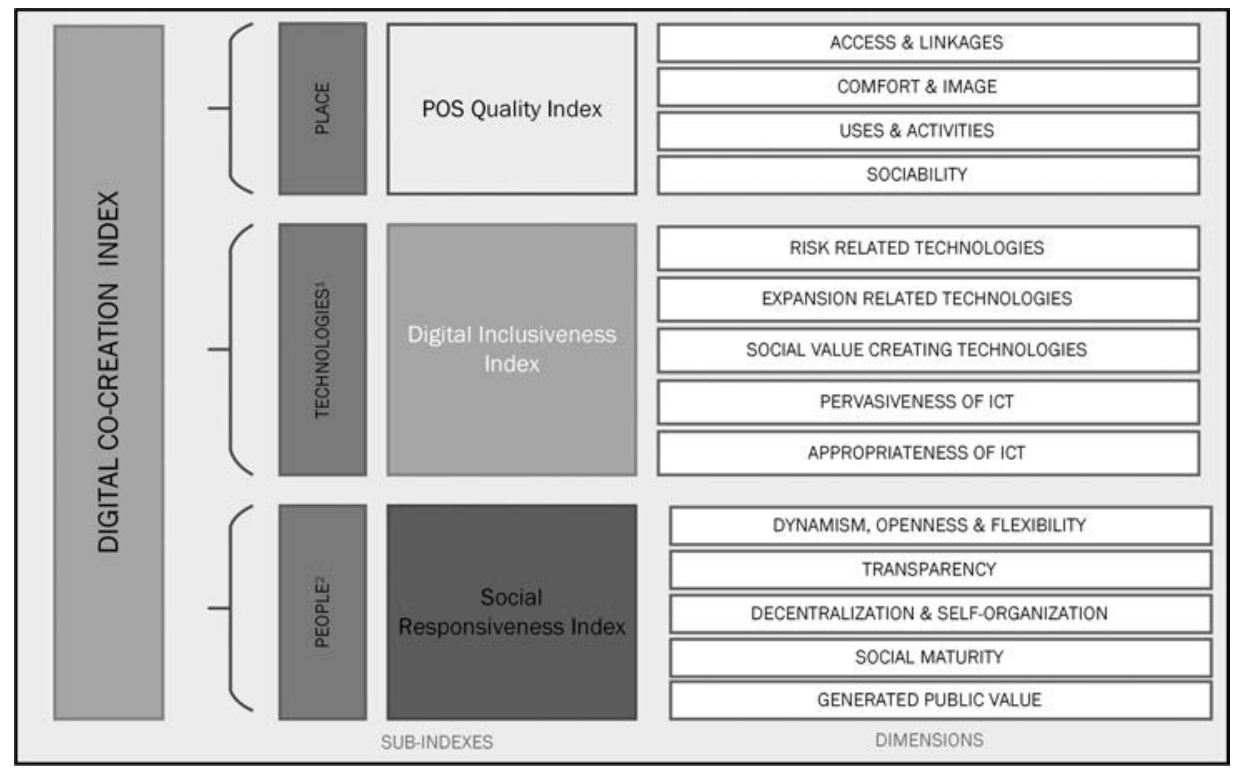

Fig. 2: Digital Co-Creation Index. Source: Mačiulienè, Skaržauskienė \& Botteldooren, 2018 
The POS Quality dimension connects the factors enhancing the social integration and communities' satisfaction with the public place generated by digital co-creation initiative. The assessment of place quality provides the context of digital initiatives and offers an operational canvas to describe and compare different case studies. In evaluating the access and linkages dimension, the importance of readability, convenience for movement and accessibility is key. Comfort and refers to the level of captivation, comfort, cleanness, and safety in the analysed space. Uses and activities dimension divides into the level of equipment, level of vitality and variety of activities available in the public space. In the analysis of sociability the factors of welcoming, level of publicness, interactivity and diversity influence the co-creative outcomes.

The Digital Inclusiveness of co-creative initiatives can be assessed through five interrelated levers. In evaluating risk-related technologies, the experts stressed the importance of security and privacy assurance tools. Expansion-related technologies refer to the availability of networking and collaboration technologies. The social value of technologies divides into the following evaluation criteria based on the expert insights: availability of data collection and access technologies, knowledge-creation technologies and decision-making technologies. The pervasiveness of ICT tools refers to the ability of the digital tools to easily function when and where needed and appropriateness of tools refers the capabilities of digitals tools in solving the issues put forward by the stakeholder groups related to the public space.

In reflecting on the Social Responsiveness dimension, the interviews led to the identification of eleven evaluation criteria. Dynamism, openness and flexibility dimension divides into criteria of interaction and engagement degree, the supply of critical mass and degree of diversity in the source of ideas. In discussing transparency issues in digital tools, two criteria were established the development of transparent structure and degree of independence. Decentralization and self-organization dimension evaluates by determining its' degree (availability of common norms and shared mental models). The social maturity dimension analyses the issues of social impact on community stakeholders, social motivation and social orientation. In evaluating generated public value two criteria are important- efficiency of problemsolving and new qualities in form of ideas, structured opinions.

The selection of criteria was performed based on possibilities for implementation, feasibility and adaptability of the framework. It must be noted that the subjectivity in the choice of dimensions and criteria is inevitable given the diffuse nature of the concept of co-creation and the lack of more straightforward definitions. However, the goal was to offer a generalized approach to undertaking the evaluation of digital co-creation initiatives. The overall intention was to ensure that the key dimensions of concern are assessed in similar ways. The assessment criteria provide a context for measurable impacts and offer an operational tool to describe and to compare the different public open spaces. The proposed criteria are interdependent and not 
mutually exclusive. The framework was not intended to be prescriptive but should offer an organizing framework which can be adapted to the needs of the user. The assessment is a crucial aspect of the implementation of any initiative, as it provides the context for its impacts to be measurable and offers the operational tools to compare the different cases, as well as the same case before and after the strategy implementation.

\section{CASE STUDY CONTEXT AND METHOD}

\section{Context of the Aukštamiestis Transformation}

Möller (2017) states that in investigation of new and complex topics (e.g. digital co-creation, living labs), it is appropriate to include the context of the examination object in the study. The case study chosen for testing the methodological assessment framework is the Aukštamiestis Living Lab. Living Lab is a place-based concept that utilises the place as a test-bed for innovation and knowledge generation through experiential learning, a combination of concrete experiences, observations, reflections, and the formation and testing of new concepts. Such an approach turns the users into value creators and enables them to explore emerging ideas, innovative concepts, and breakthrough scenarios together with the facilitators (Steen \& Bueren, 2017). The selected Living Lab is located in the industrial district of Naujamiestis (New Town) in Vilnius, Lithuania. The Lab was chosen for several reasons, mostly because the transformation of the district is conducted through bottom-up initiatives by creative communities residing in the area. The community implements a wide variety of local experimental projects of a participatory nature - workshops, seminars, festivals, open galleries - with the aim is to develop innovative urban solutions. Hence, it has huge co-creation capacity. Also, the initiators of the Living Lab synthesize the physical and virtual interactions in the space to reach desired outcomes. The Living Lab serves as a platform and a breeding ground for transformative innovations by providing supportive conditions.

The case is unique because it illustrates the transformation of urban space from private to public. The Aukštamiestis Living Lab exemplifies the modern problem of defining the private and public spaces. In the basic sense, the difference between private and open space is defined by its accessibility to outsiders - public space is open to everyone for their use and the private place is open to those permitted by law or custom (Jackson, 1974). However, in reality, this difference is way more complicated - rarely is a space either public or private. The line differentiating private and public spaces is often blurred and spans on a continuum. The Aukštamiestis Living Lab is a great example of such indistinctness. Kohn (2004) defines such spaces as privately owned social spaces and refers to art centres, markets, and shopping malls. Privately owned social spaces combine the elements of both (open/private) and have a set of limits on who can use it and for what reason (Kohn, 2004). 
The selection of the case study object imposes several limitations. The lack of publicly available, reliable information complicated the analysis efforts. The main source of knowledge on the Living Lab, it's community and activities, is the digital media. Also, the research on the object is rather limited especially from a perspective of social sciences. However, two workshops for urban planners, architects and stakeholders were organized in 2015 and 2016 in the scope of the Living Lab, which provided new research-based insights.

\section{Method for Case Study Analysis}

The goal of the chapter is to explore the applicability of methodological assessment framework in selected case. The research environment (i.e. lacks clearly defined stakeholders, limited amount of documentation) cannot be clearly specified. For this purpose, exploratory case study approach has been adapted. The exploratory case study explores situations with no clear, or single, sets of outcomes. In social research, according to Gallivan (1997), the use of one method can be considered as one-sided and non-inclusive. Hence, the analysis of the transformational processes in Aukštamiestis required the analysis of different sources of information (observation, interviews, questionnaires, documents, artefacts etc.). The study employed three research methods of qualitative nature: Stakeholder Interviews, Digital Monitoring and Document Analysis.

Digital monitoring. First of the empirical methods applied to research the Living Lab was non-formal and non-participatory digital data monitoring. Non-formal observation aims to gain data when there is little knowledge of the situation investigated. In such research, genuineness is an important feature - natural environment and data are collected in real-life situations and adapted to the natural course of events. Digital monitoring required to develop a research instrument - data collection template - based on the assessment framework presented in Section 2. A data collection template makes the web-based monitoring process uniform and allows to discern the patterns between places, people and technologies. The fieldwork was done in the period of May 2018 - August 2018 by the C3Places research group in Vilnius. The website content analysis provided insights on various aspects of website content, features and the presence of web analytic code. The research group monitored the activity of Aukštamiestis community in online social networks and content changes on their websites. In addition, publications on Loftas events and philosophy were collected to get familiar with the context of the study. The data were collected using manual and automated web-scrapping techniques.

Stakeholder interviews. The main method used to conduct stakeholder interviews was a semi-structured interview. Semi-structured interviews permit the researcher to have a list of theme and questions to covered in the interview, but it may have a flexible and fluid-structure depending on the flow of the conversation (Mason, 2002). The interview method enables evaluation of broader context and provides innovative 
and flexible ways to interpret the situation. The interviews were conducted in the period of May-August 2018. The data were transcribed and coded.

Considering that the randomized sampling is not suitable for qualitative research (Hennink, Hutter, \& Bailey, 20I I), expert sampling was employed. In the context of this study, the validity and significance of the results are based more on to the richness of the data collected and the sample selected and the competencies of the researchers to analyse the data than on the size of the sample (Patton, 2002). Five interviews with the stakeholders of Aukštamiestis were conducted, detailed in Table I. The snowballing method, asking interviewees for suggestions of additional stakeholders, was then used to identify additional contacts.

\begin{tabular}{|l|l|}
\hline Code & Expertise, relation to Aukštamiestis Living Lab \\
\hline PI & Strategic manager at Art Factory Loftas, initiator and manager for Aukštamiestis Lab community \\
\hline P2 & Head of Naujamiestis Seniors club, active participant in Aukštamiestis Living Lab events \\
\hline P3 & Active senior participant in Aukštamiestis Living Lab events, member of club "Life is beautiful” \\
\hline P4 & Architect, participant of the workshops for renewing Aukštamiestis \\
\hline P5 & Urban planner, participant of the workshops for renewing Aukštamiestis \\
\hline
\end{tabular}

Table I: Interview participants

Document analysis. In-depth examination of the documents included identifying its overall purpose, parties involved, inclusion goals, mechanisms for achieving those goals, detailed action steps, and evaluation plans of the Living Lab and the district.

The qualitative research methods gain growing importance in contemporary social sciences. Qualitative research process aims to obtain insights on processes and value individuals assign to social situations (Hesse-Biber \& Leavy, 2006). In the context of this research project, qualitative research allows to collect and analyse the empirical evidence from different stakeholders' perspectives. The case study approach also has limitations. Mostly because it introduces layers of subjectivity during the implementation, evaluation and presentation of the results. However, the research environment limits the choice of other methodological approach.

\section{DISCUSSION ON CASE STUDY RESULTS}

This section details the results of the three research studies. The goal of this empirical research exercise was to evaluate the patterns of content in relation to the conceptual model presented in Section 2. The analysis of collected qualitative content linked the insights of the literature review with the outputs of empirical research - data, categories, context.

\section{POS Quality Aspects in Aukštamiestis Living Lab}

The POS Quality Index connects the factors enhancing the social integration 
and communities' satisfaction with the public place generated by digital co-creation initiative. According to Puerari et al. (2018:12) the Living Labs "that make use of existing urban buildings and constructions actively shape the place's meaning and the socio-spatial context with the activities that they are running, both at the prominent site and beyond". Hence, the assessment of place quality provides the context of digital initiatives. In evaluating the access and linkages dimension, the importance of readability, convenience for movement and accessibility is key. The analysis of data collected through the use of POS Quality Index revealed the Living Lab is an established organization with a managerial centre - Loftas Art Factory. The space is open and accessible to variety of stakeholder groups (P4). However, it is perceived as a place for youth. Comfort and image refers to the level of captivation, comfort, cleanness and safety in the analysed space. Poplin et al. (2017) suggests that the description of a place cannot be reduced to its objects, but also must contain descriptions of the atmosphere felt at these places. Hence, the background of this territory is an important feature. The centre of Living Lab - Loftas Art Factory is based in an old radio factory. This historical feature is highly marketed in the communications of the community (P5). Background of this territory is an important topic. This fact was mentioned in the interview with senior participant (P3): "Yes, I have been to Elfa factory and research centre. They made innovative ultrasound engines and other devices. I have pleasant memories about this place, modern production processes and high level popular products". The experience at these places was very important to the participants. Goodchild (201 I:I) claims that there is a "fundamental tension with the informal world of human discourse, and nowhere is this more apparent than over the vague concept of place."

Uses and activities dimension divides into level of equipment, level of vitality and variety of activities available in the public space. The community hosts variety of events - festivals, discussions and workshops. The contextual conditions allow the Living Lab to be active in different domains and on various topics (P4). In analysis of sociability the factors of welcoming, level of publicness, interactivity and diversity influence the co-creative outcomes. The Aukštamiestis Living Lab is a setting for community activities, public life, community organization. The Aukštamiestis district is currently undergoing a creative conversion from a private space to a public space. This part of town has extensive industrial heritage and therefore a huge creative potential (P5). Jia (20I0) states that the transformations of industrial districts may bring a renaissance in the neighbourhood. The author provides the examples of Ruhr Park, High Line in New York and Art District in Beijing to illustrate this trend. The vision of Aukštamiestis too is a metropolitan industrial district with creative and entertaining solutions.

Limitations identified for the methodological framework. In the context of the Living Lab where the social and urban processes are organized in more abstract manner and on a larger scale, it was hard to determine the spatial dimensions of 
evaluation. In addition, the evaluation framework needs a clearer view on what are the necessary and desirable aspects of a functioning co-creation space i.e. providing benchmarking guidelines on how physical spaces could enable real-time participation.

\section{Digital Inclusiveness Aspects in Aukštamiestis Living Lab}

We are living in the digital age, a period in which digital technologies serve as the infrastructure of our communications. The influence of information and communication technologies is perceptible in all spheres of life including governance, education, economy, and private lifestyles. The digital tools of co-creative initiatives are crucial in urban transformations. According to Eberlain (2018), first-hand information from the citizens collected through digital means is instrumental in shaping urban spaces because it provides previously unknown data points and creates new awareness and incentives for the community to become engaged. The Digital Inclusiveness of co-creative initiatives in Aukštamiestis Living Lab was assessed through five interrelated levers. Although, the Living Lab activities are implemented via the concept of networked community, the initiative lacks the functionalities of risk-aversion, expansion and social value creation. The digital aspects of the initiative are quite basic at the moment - a system of Facebook profiles is designed to announce various activities of the community.

In evaluating risk-related technologies, the measures of security and privacy assurance have to be discussed. The security of digital data depends on Facebook Privacy Policy. The flow of messages and comments on the Facebook Pages are not controlled or monitored. However, the interview with community leader (PI) that if any security or privacy issues would arise because of their fault - they would fix and apologize. However, they cannot control the flow of communication from website visitors. Expansion-related technologies refer to the availability of networking and collaboration technologies. Strategist of Loftas (PI) explained that expansion to their target groups is achieved through maintaining separate accounts for separate activities of the community. However, more advanced solutions - chats, data collection and evaluation tools, idea collection tools - are not available. The social value of technologies divides into the following evaluation criteria based on the: availability of data collection and access technologies, knowledge-creation technologies and decision-making technologies. The interviews revealed a great interest of initiators of the Living Lab to reach various stakeholders of the district through the means of mass media, social media and events. This need has two roots - commercial and community-building. The first one comes from the need to finance the structural changes in the district, pay for the logistics of the events and administration fees. The livelier is the district, the more people and businesses it attracts. Hence, the community-building, social awareness and partnerships in the area are of key importance. The pervasiveness of ICT tools refers to the ability of the digital tools to easily function when and where needed. The appropriateness of tools refers the 
capabilities of digitals tools in solving the issues put forward by the stakeholder groups related to the public space. The data analysis revealed that more pervasive digital strategy is missing. The strategist of Aukštamiestis (PI) explained that Aukštamiestis is an absolute grassroot movement started by enthusiasts, businesses and habitants of the district. So, more advanced platforms and tools are too expensive to be developed due to lack of financial and time resources.

Limitations identified for the methodological framework. The application of the methodological framework in analysis of the case study, showed the need to update the framework to fit the needs of digital initiatives of smaller scale i.e. those who only use social networks for people to join the events or have a website with core information. The tools and platforms enabling co-creative processes bring a number of advantages to the communities, governments and other involved stakeholders. Nevertheless, limited number of projects have limited technical skills needed to develop advanced tools. Besides knowing what different aspects the initiators should consider, it would be useful to add benchmarks allowing to evaluate the performance of current tools and applicability of tools in varying contexts.

\section{Social Responsiveness Aspects in Aukštamiestis Living Lab}

The Aukštamiestis Living Lab is developed through projects, initiatives and workshops including community members, architects, urbanists, students, municipality and other interested parties. The involved stakeholder groups and individuals thus become the sources of creativity, insight and initiative in the ever changing district. The initiative mainly relates to three groups of stakeholders: residents and their communities; owners of business and cultural spots; municipality entities. Based on the interview material, they certainly express the need for more inclusion.

Dynamism, openness and flexibility dimension refers to the openness and diversity of the initiative. In co-creative processes, there is a strong need to combine different types of knowledge to better deal with complex issues, exploring visions, possibilities, and finding agreements between stakeholders. The digital initiative is open to all citizens. Due to lack of dissemination, the networked community does not include more isolated societal groups (e.g. seniors). This social disconnection is a key barrier to new collaborative forms of developing urban transformations. In analysing the transparency structures of the Living Lab, their leader (PI) explained that the main way to engage in co-creative activities is to start living and/or working in the area. Community consists of separate house communities and socially active entities can get involved quickly. What unites Aukštamiestis is bigger ideas and purposes e.g. Open Gallery project changes the quality of life to everyone who is located around by adding more colours, traffic and liveability. Because of the increased traffic, the businesses are keen to get involved and even finance different projects. Decentralization and self-organization dimension evaluates the organizational structures of initiatives. The organizational structure of the Living Lab is in place - the initiators 
have know-how on event organization and community building. However, they are missing skills and/or drive for inclusion of varied stakeholder groups. Yet only leaders are clear in both online and offline community, neither hierarchy nor funding is guaranteed for Aukštamiestis community.

The social maturity dimension analyses the issues of social impact on community stakeholders, social motivation and social orientation. According to Rohe (2004), the collective actions at the level of district provides a self-reinforcing model of civic engagement and social capital - engagement begets new relations, which leads to greater trust and trust brings effective collective actions resulting in individual and social benefits. The motivation to solve social problem (e.g. exclusion of senior citizens) is quite high - the initiators show high levels of excitement. The initiators suggest that the Living Lab was established out of dissatisfaction with the current living environment. However, there is a lack of skill, personnel and especially time to create a comprehensive and efficient digital communication strategy. In evaluating generated public value two criteria are important - efficiency of problem-solving and new qualities in form of ideas, structured opinions. In the perspective of urbanism, Aukštamiestis Living Lab was inspired by the experiences in other cities and willingness to bring this culture to Vilnius. The start of the initiative was met with pessimism $(\mathrm{PI})$. However, the organizational efforts of the volunteers and habitants led to more cultural events, workshops and new forms of social innovation. The help of municipality was introduced only recently, mainly because of newly elected mayor (PI: It was a huge change in attitude since new mayor. Till then we were even not allowed nearer. Now there is a dialogue. Maybe not so many opportunities yet, but there is a dialogue, we are talking about community projects, proposing tools). The social impact and changed environment of the district became a further stimulus for the initiators and volunteers to develop new projects.

Limitations identified for the methodological framework. The application of the methodological framework in analysis of the case study, showed that social responsiveness dimension lacks a clearer evaluation of the roles of involved stakeholder groups. The analysis of research outputs, especially the material of interviews, showed that the role of pro-active stakeholder groups is crucial in transformation processes. Besides knowing what different types of stakeholders are to be considered in making the places more attractive, the question arises how and when they need to be involved in the co-creative process aimed at long-term social transformations.

\section{CONCLUSIONS AND RECOMMENDATIONS}

Digitally enhanced public open spaces are ideal environments for the social innovations to emerge due to the involvement of stakeholders and ICT in the knowledge creation. Although there is broad agreement that ICT application in public governance leads to benefits for society, they should not be seen as an antidote to all problems. The technology is an enabler increasing the diffusion of information and 
acts as a fundamental dimension of social change, but technology alone is not capable of fuelling the collaboration. Digital co-creation entails preconditions and challenges due to the diverse backgrounds of actors involved and variety of theoretical viewpoints analysing the processes. Hence, there is an urge to provide holistic approach and investigate the prevalence of the digital initiatives in urban planning. The Digital Co-Creation Assessment Framework focuses on facilitating a framework to evaluate digital co-creation initiatives aimed at improvement of public spaces and identify cases that can be potentially transformed into co-creative systems. Proposed model allows understanding of each of the components of the model and, to add holism to the relationship between them.

However, definition of complex socio-technical systems, such as digital co-creation, is unavoidably partial, context-specific and temporary. The application of the methodology in analysis of Aukštamiestis Living Lab was the first exercise in the iterative revision and testing of the model. The choice of case study method provided an in-depth analysis of a particular setting - transformation of a private space to open place. The exploratory case study of Aukštamiestis Living Lab provided a general understanding for improvement of methodological framework i.e. the need for benchmarking guidelines on how physical spaces could enable real-time participation, evaluation criteria for digital initiatives of smaller scale and how and when different stakeholders need to be involved in the co-creative process. Additional work is needed to formulate measures and indicators of successful initiatives. Digital co-creation encompasses many different interpretations subjected by researchers and disciplines. Various parties are likely to hold different views on the concept. Proposed model offers dynamic ideas for future researches to further conceptualize the underlying perspectives of co-creation. The proposed model needs to be tested in additional cases to further verify its validity and usefulness in diverse settings.

\section{REFERENCES}

Baldersheim, H., \& Kersting, N. (2012). The wired city: A new face of power? A citizien perspective. In J. Peter, K. Mossberger, S. E. Clarke (Eds.). The Oxford handbook of urban politics (590-606). New York, NY: Oxford University Press.

Bason, C. (2015). Leading public sector innovation: Co-creating for a better society. Bristol, UK: Bristol University Press.

Birch, E. L. (2016). Public and Private Space in Urban Areas: House, Neighborhood, and City, (July 20I0). http://doi.org// 0.1007/978-0-387-32933-8

Brabham, D. C. (2009). Crowdsourcing the Public Participation Process for Planning Projects. Planning Theory, 8(3): 242-262. https://doi.org//0.1 I77//473095209/04824

Bulc, V. (20I2). New organizational and social paradigm: From cooperation to co-creation and sustainable coexistence. Journal of Organisational Transformation \& Social Change, 9(I): 29-39. doi: I0.1386/ jots.9.1.29_I. 
Castells, M. 2000. The Information Age: Economy, Society and Culture, 2nd ed. Blackwell Publishers, Oxford

Certomà, C., Dyer, M., Pocatilu, L., \& Rizzi, F. (Eds.). (2017). Citizen Empowerment and Innovation in the Data-Rich City. New York, NY: Springer International Publishing.

Cheliotis, K. (2015). Capturing real-time public space activity using publicly available digital traces. (Technical Report No. 16-16). The Workshops of the Tenth International AAAI Conference on Web and Social Media. Retrieved from

Eberlain, S. (2018). Urban Metabolism: A Real World Model for Visualizing and Co-Creating Healthy Cities. Retrieved December 12, 2018, from https://www.thenatureofcities.com/2018/07/24/ urban-metabolism-real-world-model-visualizing-co-creating-healthy-cities/

Faga,B. (2006).Designing Public Consensus. NewYork: John Wiley.

Franz, Y. (20I5). Designing social living labs in urban research. Info, 17(4), 53-66. http://doi.org/ 10.1 I08/info-0I-2015-0008.

Gallivan M. J. (1997) Value in Triangulation: A Comparison of Two Approaches for Combining Qualitative and Quantitative Methods In Information Systems and Qualitative Research (ed. Lee A.S.et al.) Springer Science+Business Media Dordrecht.

Griggs, K. \& Wild, R. (2013). A Social Networking Adoption Model for Communication and Collaboration in e-Government (Vol. I). In W. Castelnovo, E. Ferrari (Eds.), Proceedings of thr I3th European Conference on eGovernment (pp. 221-229). Como: Department of Theoretical and Applied Sciences. University of Insubria.

Hennink, M., Hutter, I. \& Bailey, A. (20II). Qualitative Research Methods. Thousand Oaks: SAGE Publications Ltd.

Hesse-Biber, S. N. \& Leavy, P. (2006). The practice of qualitative research. Thousand Oaks, CA: Sage.

Yin, R. K. (2009). Case Study Research: Design and Methods. Thousand Oaks, SAGE.

Jabareen, Y. (2009). Building a conceptual framework: philosophy, definitions, and procedure. International Journal of Qualitative Methods, 8(4), 49-62. https://doi.org/I0.I I 77/I60940690900800406

Jackson, M. H. (1997). Assessing the structure of communication on the world wide web. Journal of Computer-Mediated Communication, 3(1): I-I5.

Jia, X. (2010). Transformation of Industrial Space. Tennessee Research and Creative Exchange.

Kohn M, 2004, Brave New Neighbourhoods: The privatisation of public spaces, London: Routledge

Mačiulienė M., Skaržauskienė A. \& Botteldooren D. (2018) Developing Digital Co-Creation Assessment Methodology for Social Innovation in Public Spaces. Contemporary Economics. Warsawa: Faculty of Management and Finance: University of Finance and Management in Warsaw. 2018 (I2) 4.

Mačiulienè, M. (2018). Modelling Co-Creative Ecosystem in the Context of Technological Development. Vilnius: Mykolas Romeris University.

Martinus, K. (2014). Can Public Space be a Platform for Social Innovation? A Study of Sannomiya, Kobe, Japan. Japan Social Innovation Journal, 4(I): 44-54.

Möller, K. (2017). Questioning the theory-praxis gap in marketing - types and drivers of research implementation. European Journal of Marketing, 5I(7/8): II63-II72.

Möller, S. \& Raake, A. (2014) Quality of Experience-Advanced Concepts, Applications and Methods; Springer: Cham, Switzerland.

Mulder, I. (20I2). Living Labbing the Rotterdam Way: Co-Creation as an Enabler for Urban Innovation. Technology Innovation Management Review, 2, 39-43.

Patton, M. Q. (2002). Qualitative Evaluation and Research Methods. Thousand Oaks, CA: Sage Publications. 
Poplin, A. (2012). Playful public participation in urban planning: A case study for online serious games. Computers, Environment and Urban Systems, 36(3): 195-206. doi: 10.1016/j.compenvurbsys.20I I.10.003

Poplin, A., Yamu, C. \& Rico-gutierrez, L. (2017). Place-making: an approach to the rationale behind the location choice of power places. lowa State University as case study. In The International Archives of the Photogrammetry, Remote Sensing and Spatial Information Sciences, XLII-4 (W3): 73-8I.

Project for Public Spaces (2009). What Makes a Successful Place? Available at https://www.pps.org/ reference/grplacefeat

Projects. Planning Theory, 8 (3): 242-262. https://doi.org// 0.I I77//473095209 I04824.

Puerari, E., Koning, J. I. J. C. de, Wirth, T. von, Karré, P. M., Mulder, I. J. \& Loorbach, D. A. (2018). Co-Creation Dynamics in Urban Living Labs. Sustainability, I0(I893): I-I8. http://doi.org//0.3390/su I006/893

Rumbul, R. (2016). ICT and citizen efficacy: The role of civic technology in facilitating government accountability and citizen confidence. IFIP Advances in Information and Communication Technology, 48I: 213-222.

Shenk, L., Anderson, N. \& Passe U. (20I6). Engaged science and working with youth for sustainable cities: A partnership between "East High Cares" and an lowa State University research team. Confronting the Challenges of Public Participation: Issues in Environmental, Planning and Health Decision-Making, Ames, lowa, USA, Charleston, SC: CreateSpace.

Skaržauskienè, A.; Ewart, J.; Krzywosz-Rynkiewizc, B.; Zalewska, A.; Leichteris, E.; Mačiulis, A.; McLean, H.; Mickunas, A.; Mikulskienè, B.; Paražinskaitè, G.; (20I5). Social Technologies and Collective Intelligence; Mykolas Romeris University: Vilnius, Lithuania.

Stewart-Weeks, M. (2010). Social Innovation \& The City: What is the Connection between Social Innovation and Urban Innovation and Why Does it Matter? Social Spaces, 80-83. Retrieved from https://ink.library.smu.edu.sg/lien_research/49

Varna, G. and Tiesdell, S. (20I0). Assessing the Publicness of Public Space: The Star Model of Publicness, Journal of Urban Design, 15(4): 575-598. 